\title{
Can Pneumothorax be the Cause of Aspergilloma?
}

\section{Pnömotoraks Aspergilloma Nedeni Olabilir mi?}

Onur Derdiyok, Levent Alpay, Volkan Baysungur

\begin{abstract}
Bullectomy and pleurodesis are frequently used for the surgical treatment of spontaneous pneumothorax. Bullectomy and pleurodesis are combined to prevent recurrence, but when pleurodesis causes chest wall and bullous lung neovascularization, it is applied particularly to the apical region. The resulting sterile area, however, may lead to many complex clinical problems, such as aspergillus. In the present study we present a case who underwent a right upper lobectomy due to hemoptysis complications related to aspergilloma, arising from the sterile space in the right hemithorax after a tube thoracostomy performed 7 years previously.
\end{abstract}

Key words: Aspergilloma, pneumothorax, sterile space.

\section{Özet}

Spontan pnömotoraksın cerrahi tedavisinde bülektomi ve plörodezis genellikle kullanılmaktadır. Bullektomi ve plöredez nüksü önlemek için birlikte uygulanır. Bununla birlikte, plöredez göğüs duvarı ve büllöz akciğer neovaskülarizasyonuna neden olduğunda, özellikle apikal bölgede uygulanır. Ancak, ortaya çıkan steril alan, Aspergillus gibi birçok karmaşık klinik problemle sonuçlanabilir. Bu çalışmada, 7 yıl önce yapılan tüp torakostomi sonrası, sağ hemitoraksın steril alanından kaynaklanan aspergillomaya bağlı hemoptizi komplikasyonları nedeniyle sağ üst lobektomi yapilan olgumuzu sunuyoruz.

Anahtar Sözcükler: Aspergilloma, pnömotoraks, steril alan.
Department of Thoracic Surgery, University of Heath Sciences Sureyyapasa Chest Diseases and Thoracic Surgery Training and Research Hospital, Istanbul, Turkey
Sağılık Bilimleri Üniversitesi Süreyyapaşa Göğüs Hastalıkları ve Göğüs Cerrahisi Eğitim ve Araştırma Hastanesi Göğüs Cerrahisi Kliniği, İstanbul

Submitted (Başvuru tarihi): 25.03.2019 Accepted (Kabul tarihi): 31.05 .2019

Correspondence (iletişim): Onur Derdiyok, Department of Thoracic Surgery, University of Heath Sciences Sureyyapasa Chest Diseases and Thoracic Surgery Training and Research Hospital, Istanbul, Turkey

e-mail: derdiyokonur@gmail.com 
Aspergillus infection of the lungs occurs over a wide spectrum, from saprophytic colonization to hypersensitivity reactions and pneumonia (1). Chronic pulmonary aspergillosis is a rare and problematic pulmonary disease that affects around 240,000 people in Europe who suffer from many other respiratory diseases. Subacute invasive pulmonary aspergillosis is an endobronchial disease (formerly known as chronic necrotizing pulmonary aspergillosis) that is usually referred to as rapid invasive aspergillosis ( $<3$ months) in immunocompromised patients (2). The present study presents the case of a patient who underwent a right upper lobectomy for aspergilloma with references to literature.

\section{CASE}

A 30-year-old male patient who admitted to our clinic with hemoptysis 5 months previously was found to have no obvious anomalies upon physical examination. Blood pressure was 130/85, pulse was 90 , temperature was $36.5^{\circ} \mathrm{C}$ and respiratory rate was 24 . The white blood cell count was 6300 (66.3\% neutrophils, 14\% lymphocytes), erythrocyte sedimentation rate was $68 \mathrm{~mm} / \mathrm{h}$ and other laboratory parameters were within normal limits. A posterior anterior $(\mathrm{PA}) \mathrm{X}$-ray showed an increased density in the right upper hemithorax (Figure 1). A computerized tomography (CT) revealed a $3 \mathrm{~cm}$ cavitary lesion in the upper lobe of the right lung that was compatible with aspergilloma (Figure 2). The patient in the present study had undergone a tube thoracostomy 7 years previously after suffering a pneumothorax (Figure 3). The patient had no tuberculosis history, and the CT 7 years previously had identified a sterile space on the right hemithorax in the upper zones (Figure 4). No endobronchial lesion was detected on a fiberoptic bronchoscope. Sputum and bronchoscopic lavage cultures revealed no proliferation and a cytological examination revealed no malignancy. No acid-fast bacilli were found. Agglutinin tests for hydatid cysts were negative. Lung function test results were within normal limits (FEV1: $2.6 \mathrm{~L}$ to 96\%). A right upper lobectomy was performed by thoracotomy. The pathology and microbiology results both reported aspergillosis.

\section{DISCUSSION}

Aspergillus is a human pathogen, with pulmonary aspergillosis being more frequently detected in patients with weak immune systems. In the saprophytic form of the disease, aspergillomas settle in pre-existing cavities.
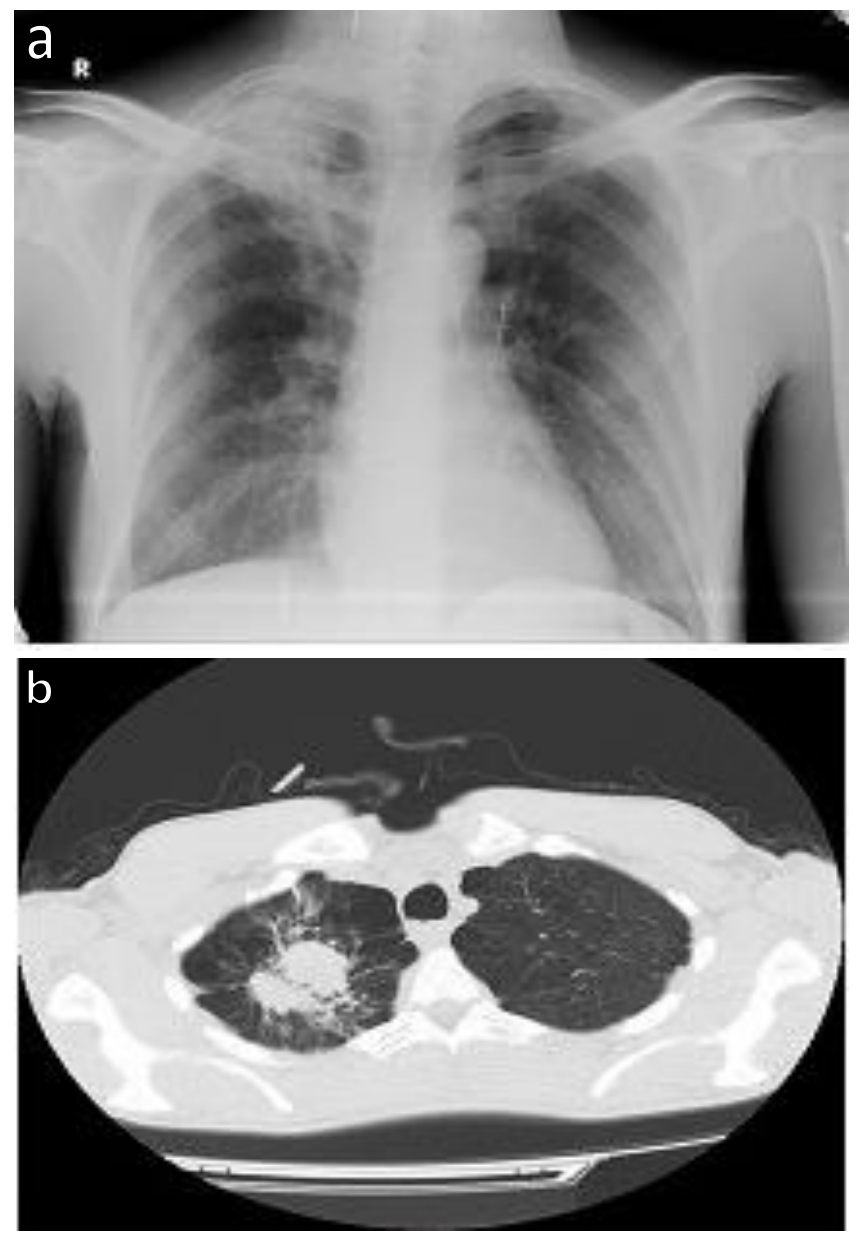

Figure 1: PA X-ray showing an increase in density in the right upper hemithorax (a) A CT was performed on the right upper lobe of the right lung after a caudal lesion compatible with aspergilloma of approximately $3 \mathrm{~cm}$ was identified (b)

A slowly progressive infiltrate-producing aspergillosis in a chronic cavitary form was identified in 1981 as a new group of lung including semi-invasive mycetomas (3-5). Aspergillus is a fungus that enters the body through the inhalation of airborne spores, with Aspergillus airway colonization seen most often in patients with an underlying chronic airway disease, such as asthma, bronchiectasis or cystic fibrosis. Patients with a clinically compatible disease and characteristic radiological findings are classified as probable cases of aspergillus fluid in the respiratory tract, based on established criteria for patients with pulmonary infection. In pulmonary diseases such as pulmonary aspergillosis, tuberculosis, bronchiectasis or pulmonary abscess, aspergillus is a frequent problem in immunocompromised patients undergoing anticancer therapy with steroids (3). That said, it is very rare to encounter aspergillus infection in the absence of a chronic disease. In 11 cases reported in Japanese literature, no causal link was identified between pneumothorax and aspergillus infection in any of the cases, there were two cases of lung an abscess was detected. In one of the 
reported cases in Japan, it was suggested that an aspergillus infection had caused pneumothorax as a result of an infected bulla rupture (4). The causal link between pneumothorax and the aspergillus infection was not clear in our case. A sterile space associated with pneumothorax had been identified 7 years previously. Airway diseases such as cavities or bronchiectasis are important to capture airway sequel aspergillus spores. It has been reported that aspergillus colonization occurs in more than 25\% of asthmatic patients. Non-prominent clinical findings include infective pneumonia, with localized radiological forms being initially more frequent in most cases. Diagnosis is based on pathological data, but in many cases the only possible sensitivity studies are broncho-alveolar lavage and bronchial brushing, which give both sensitive and specific results (5-7). Adzic-Vukovic et al. (6) reported a case of pneumothorax associated with aspergilloma in a non-immunodeficient patient. Pneumothorax is quite rare, being a consequence of a rupture of the aspergilloma pleural space in non-immunodeficient patients. In literature, pneumothorax has been reported in granulocytopenic patients who underwent intensive cytotoxic treatment for hematological malignancies.

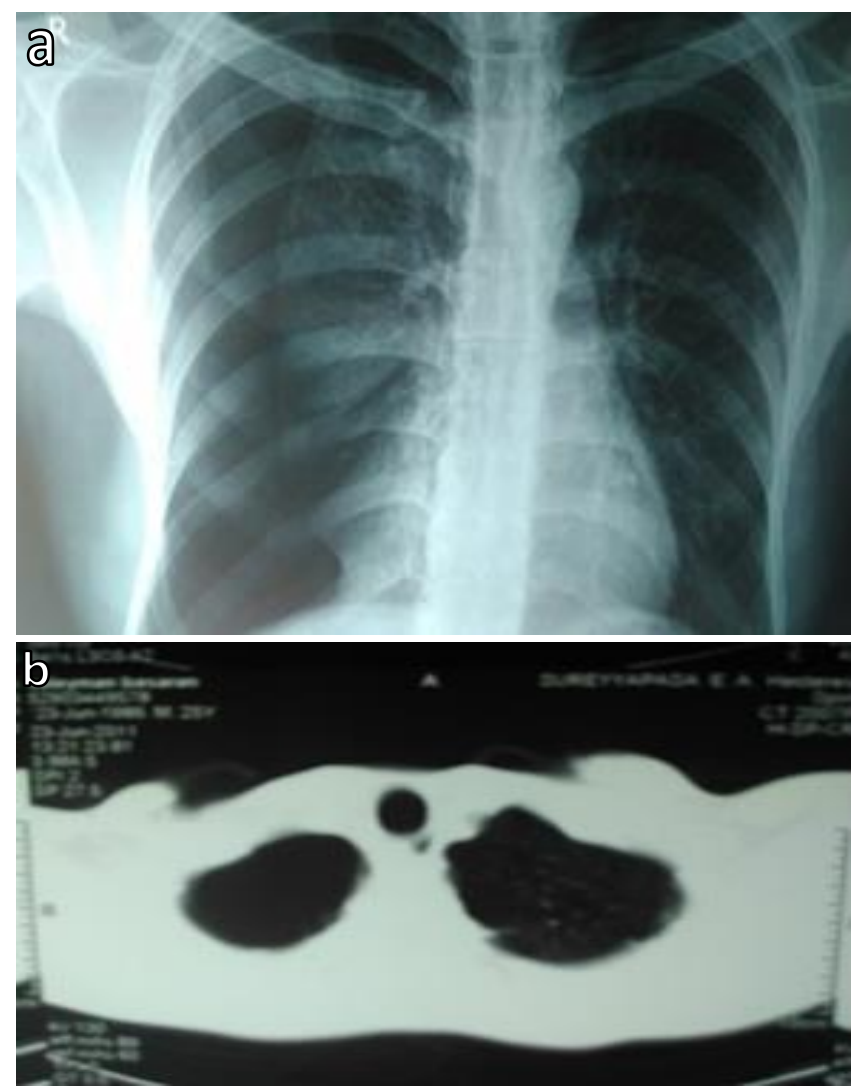

Figure 2: Seven years previously. A PA X-ray of the right hemithorax in a subtotal pneumothorax (a) A CT of the right hemithorax upper zone sterile space (b)
As in our case, it may cause aspergillus in postoperative lesions of the permanent or bullous lung beneath the thick pleura. Hemoptysis is a common symptom in aspergilloma cases.

\section{CONCLUSIONS}

It should be remembered that aspergilloma may, on rare occasions, be seen in cases without chronic disease. After pneumothorax, pulmonary aspergilloma may develop in the sterile space. Patients should be treated as a matter of urgency to prevent possible life-threatening complications, even if they are asymptomatic, and to minimize the morbidity and mortality of the operation.

\section{CONFLICTS OF INTEREST}

None declared.

\section{AUTHOR CONTRIBUTIONS}

Concept - O.D., L.A., V.B.; Planning and Design - O.D., L.A., V.B.; Supervision - O.D., L.A., V.B.; Funding - O.D.; Materials - V.B.; Data Collection and/or Processing - L.A., V.B.; Analysis and/or Interpretation - O.D.; Literature Review - O.D.; Writing - L.A.; Critical Review - O.D.

\section{YAZAR KATKILARI}

Fikir - O.D., L.A., V.B.; Tasarım ve Dizayn - O.D., L.A., V.B.; Denetleme - O.D., L.A., V.B.; Kaynaklar - O.D.; Malzemeler - V.B.; Veri Toplama ve/veya İşleme - L.A., V.B.; Analiz ve/veya Yorum - O.D.; Literatür Taraması O.D.; Yazıyı Yazan - L.A.; Eleştirel İnceleme - O.D.

\section{REFERENCES}

1. Seyedmousavi S, Bosco SDM, De Hoog S, Ebel F, Elad D, Gomes RR, et al. Fungal infections in animals: a patchwork of different situations. Med Mycol 2018; 56 (Suppl 1):165-87. [CrossRef]

2. Denning DW, Cadranel J, Beigelman-Aubry C, Ader F, Chakrabarti $A$, Blot $S$, et al. Chronic pulmonary aspergillosis: rationale and clinical guidelines for diagnosis and management. Eur Respir J 2016; 47:45-68. [CrossRef]

3. Matsumoto S, Takenaka K, Maezono K. Two cases of Aspergillus infection detected during surgery for pneumothorax. J Jpn Assoc Chest Surg 1999; 13:654-9. [CrossRef]

4. Kobashi K, Kimura M, Tano Y, Matsushima T. Chronic necrotizing pulmonary aspergillosis complicated by pneumothorax. Nihon Kyobu Shikkan Gakkai Zasshi $1996 ; 34: 210-5$. 
5. Patterson TF, Thompson GR, Denning DW, Fishman JA, Hadley S, Herbrecht R, et al. Practice guidelines for the diagnosis and management of aspergillosis: 2016 update by the Infectious Diseases Society of America. Clin Infect Dis. 2016; 63:e1-e60. [CrossRef]

6. Vukicevic TA, Dudvarski-llic A, Zugic V, Stevanovic G, Rubino S, Barac A. Subacute invasive pulmonary asper- gillosis as a rare cause of pneumothorax in immunocompetent patient: brief report. Infection 2017; 45:377-80. [CrossRef]

7. Gupta PP, Fotedar S, Agarwal D, Magu S, Saini K. Pneumothorax: a rare presentation of pulmonary mycetoma. Ann Thorac Med 2007; 2:171-2. [CrossRef] 